\title{
Miracle Child
}

The Journey of a Young Holocaust Survivor 
The Holocaust:

History and Literature, Ethics, and Philosophy

Series Editor

Michael Berenbaum (American Jewish University)

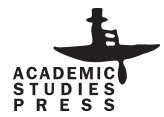




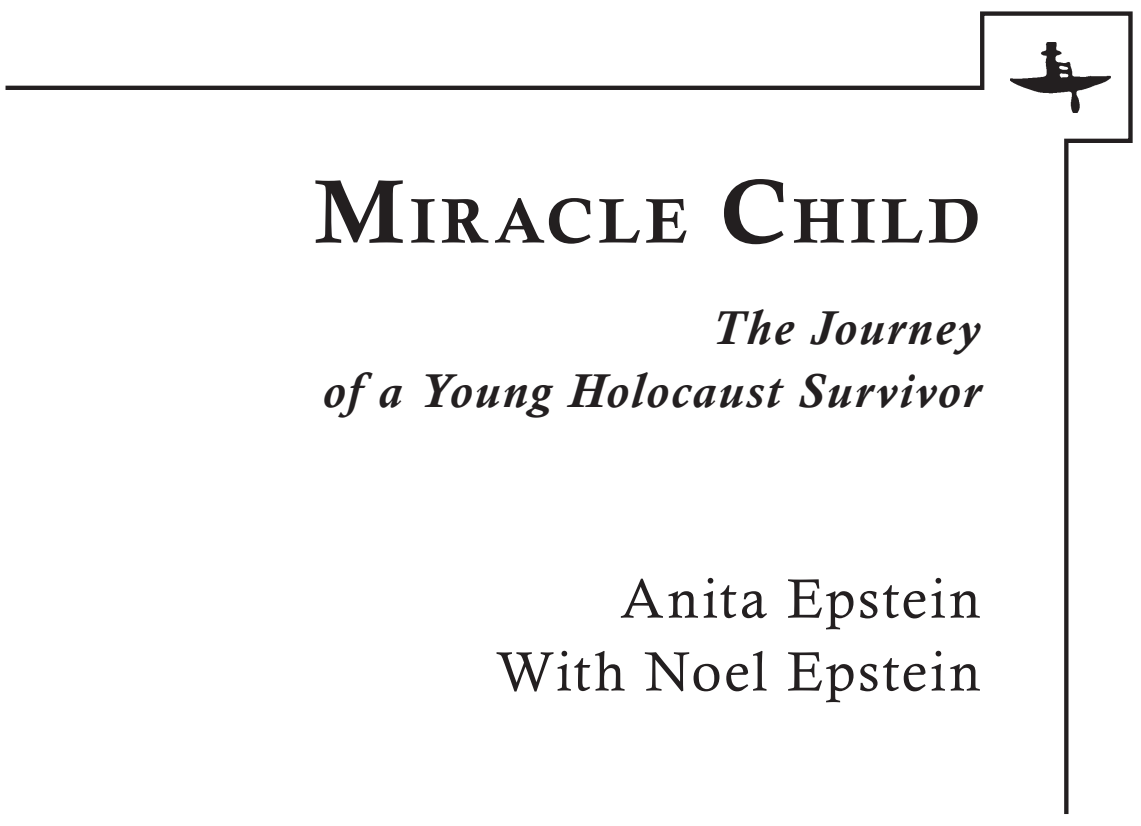

Boston

2018 
Library of Congress Cataloging-in-Publication Data:

The bibliographic data for this title is available from the Library of Congress.

Copyright (C) 2018 Academic Studies Press

All rights reserved.

ISBN 978-1-61811-858-5 (hardback)

ISBN 978-1-61811-859-2 (paperback)

ISBN 978-1-61811-860-8 (electronic)

Cover design by Ivan Grave.

Published by Academic Studies Press in 2018

28 Montfern Avenue

Brighton, MA 02135, USA

press@academicstudiespress.com

www.academicstudiespress.com 
For our grandchildren,

Tessa, Jacob, Lilah, Max and Eli 
Anyone who doesn't believe in miracles is not a realist.

-David Ben-Gurion 